\title{
Gør køn en forskel? \\ Hvad fortæller studerende på universitetet om køn og studier på nordisk og kemi?
}

\section{Af Kirsten Reisby}

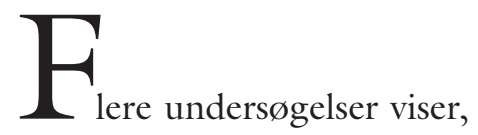
at der stadig er en stærkt ulige fordeling $\mathrm{i}$ Danmark, når det gælder kvindelige og mandlige lektorer og professorer på universiteter og højere læreanstalter. I de sidste femten år har kvinder stort set uændret udgjort $17 \%$ af det faste videnskabelige personale ved landets fem universiteter, heraf udgør kvinder kun 6\% af professorerne (Jensen 1997, 28-29). Det er baggrunden for projekt "Kønnets betydning - barrierer og karrierer i de højere uddannelser og forskning", som er et af fem projekter under forskningsrådsinitiativet "Kønsbarrierer i de højere uddannelser og forskning” (1996-2001).

\section{BEGREBET KØN}

En grundlæggende antagelse i projektet er, at køn gør en forskel. Køn er en social og kulturel konstruktion. At køn og dermed kvinde og mand, kvindeligt og mandligt er konstrueret betyder, at disse kategoriers mening og betydning frembringes i samspil 
mellem mennesker og de sociale og kulturelle sammenhænge, som de indgår i. Køn er, hvad det gøres til, dvs. en social overenskomst. I den mest radikale udgave af socialkonstruktivisme betyder det, at der ikke er nogen virkelighed uden for den, der skabes af sproget.

Antagelsen i dette projekt er, at der er en virkelighed, men at den "virkelighed", vi kan fatte, er den, som vi producerer gennem begreber. Sådan også med køn. Kønnet er ikke noget fastlagt, der ligger og venter på at blive opdaget. Det bliver til i forskellige mellemmenneskelige relationer (Widerberg 1992, 289). Kvinder og mænd er selv aktører, selv med til at konstruere sociale og kulturelle forståelser af kvindeligt og mandligt og bidrager gennem deres handlinger til at skabe deres egen kønsidentitet. Køn, kvinde-mand, kan gøres på mangfoldige måder. Men det betyder ikke, at kønnet er flydende, at alle muligheder er åbne. Samfundsmæssige rammer og strukturer tillige med tolkninger af kulturelle normer, værdier og standarder interagerer $\mathrm{i}$ subjektets handlerum og er indlejret i et historisk perspektiv. Det biologiske grundlag er på samme måde underlagt både socialt betingede forandringer og kulturelle og subjektive tolkninger.

Sprogligt set er kvindelighed og mandlighed åbne og ustabile kategorier, samtidig med at kønsbegrebet ikke er kønsneutralt. Dikotome kønsstereotypier, kønsmetaforer og kønsfikserede myter er sproglige "realiteter", og som sådan er den sproglige praksis en del af kønnets "virkelighed" og den sætter sit aftryk på de konstruktioner, som subjektet forhandler sig til (Hansen 1991, Simonsen 1996). Det betyder, at historiske individer ikke selv kan vælge deres køn, ej heller kan de skifte det ud efter forgodtbefindende. Der er i vores kultur også forskel på den magt, der kan udøves gennem kvindelige og mandlige positioner i forskellige kontekster, og der er forskelle på de handlemuligheder, der i social praksis knyttes til kvinde-mand.
Det er med baggrund i en sådan forståelse af køn, at kønnets betydning bliver undersøgt i forhold til barrierer og karrierer inden for et naturvidenskabeligt og et humanistisk studium ved et universitet anno 1998, dvs. ved institutter, hvis VIP-stillinger talmæssigt er næsten totalt domineret af mænd.

\section{FORSKERREKRUTTERINGS- UNDERS $\varnothing$ GELSEN}

For at undersøge mulige betydninger af køn er der valgt tre nedslagspunkter i et studieforløb. Denne artikel udspringer af data indsamlet $\mathrm{i}$ forbindelse med den forste af tre delundersøgelser: Forskerrekrutteringsundersøgelsen. ${ }^{1}$

Denne artikel bygger på udsagn fra interview med i alt 28 studerende: syv studerende af hvert køn fra henholdsvis specialestudiet på nordisk og studerende på 8.semester på kemi. Ved slutningen af 8.semester kan kemistuderende ansøge om optagelse på forskeruddannelsens del A eller de kan gå videre $\mathrm{i}$ et kandidatstudium. På nordisk er ca. $75 \%$ kvinder, mens kvinder udgør ca. $30-40 \%$ på kemistudiet.

\section{KORT OM DESIGN OG INTERVIEWMETODE}

Grundmaterialet er de studerendes fortællinger om studieoplevelser, -erfaringer og -vurderinger samt om hverdagsliv og fremtidsforestillinger. Ved at vælge tematisk styrede gruppeinterview, også kaldet fokusgruppeinterview, kan man opnå, at der i interaktionen mellem deltagerne udveksles forskellige erfaringer og synsvinkler (Morgan 1988). Fokusgruppeinterviewet bygger på faste temaer og en løs struktureret samtaleform. Et sådant interview giver rum for dialoger mellem informanterne om forhold, som de er eksperter på. Gruppeinterviewene er suppleret med individuelle interview for at give plads til mere fyldige beretninger. I de individuelle interview er interviewerens 
opgave at lytte aktivt og spørge, således at den interviewede oplever at være i dialog.

De otte fokusgrupper har været sammensat af 2-3 personer af samme køn ud fra en antagelse om, at der lettere skabes et samtalerum mellem personer af samme køn. Til de fjorten individuelle interview er valgt én fra hver gruppe og "nye" studerende.

Udvælgelsen af interviewpersoner er sket på baggrund af besvarelsen af en spørgeskemaundersøgelse, hvor de studerende kunne svare Ja, Måske ja eller Nej til et ph.d.-forløb. Der er valgt studerende fra alle tre svargrupper. Endvidere er de studerende udvalgt til interview ud fra, at de skrev inden for forskellige specialeområder og ud fra, om de har børn/ikke børn.

Alle informanter har før interviewet fået tilsendt en temaliste. Temaerne omfatter undervisning, vejledning, "den gode lærer", det faglige og sociale miljø på instituttet, det gode speciale, forskerkvalifikationer, universitetet som arbejdsplads samt fremtidsplaner.

"Køn" er ikke et tema i gruppeinterviwene. I de individuelle interview er et tema: Mulige forskelle på kvindelige og mandlige studerende. Begrundelsen for ikke at sætte køn på den udsendte temaliste er forestillingen om, at kønnets mulige betydninger må fremstå gennem analyser af de studerendes fortællinger. Men selv om der ikke bliver spurgt til køn i interviewene, så taler de studerende om køn i løbet af interviewene. De taler om køn med reference til aktuelle medieindslag, men antagelig også begrundet i, at de på forhånd er informeret om, at projektet drejer sig om køn.

Et interview er kontekstbundet. Med den amerikanske antropolog Jean Lave kan vi tale om et - om end kortvarigt - socialt praksisfællesskab, hvor interviewdeltagerne er fuldgyldige medlemmer (Lave og Wenger 1991, Lave 1999). Samtalen udfolder sig og skabes i en interaktion under påvirkning blandt andet af formål og forventninger og deltagernes forskellige positioner (Kvale 1996).

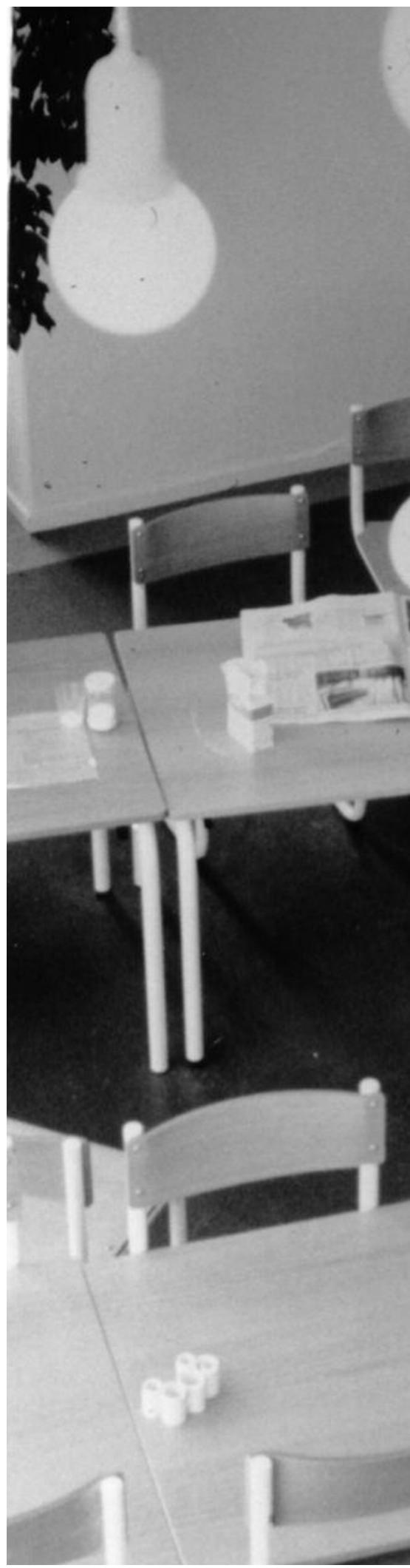




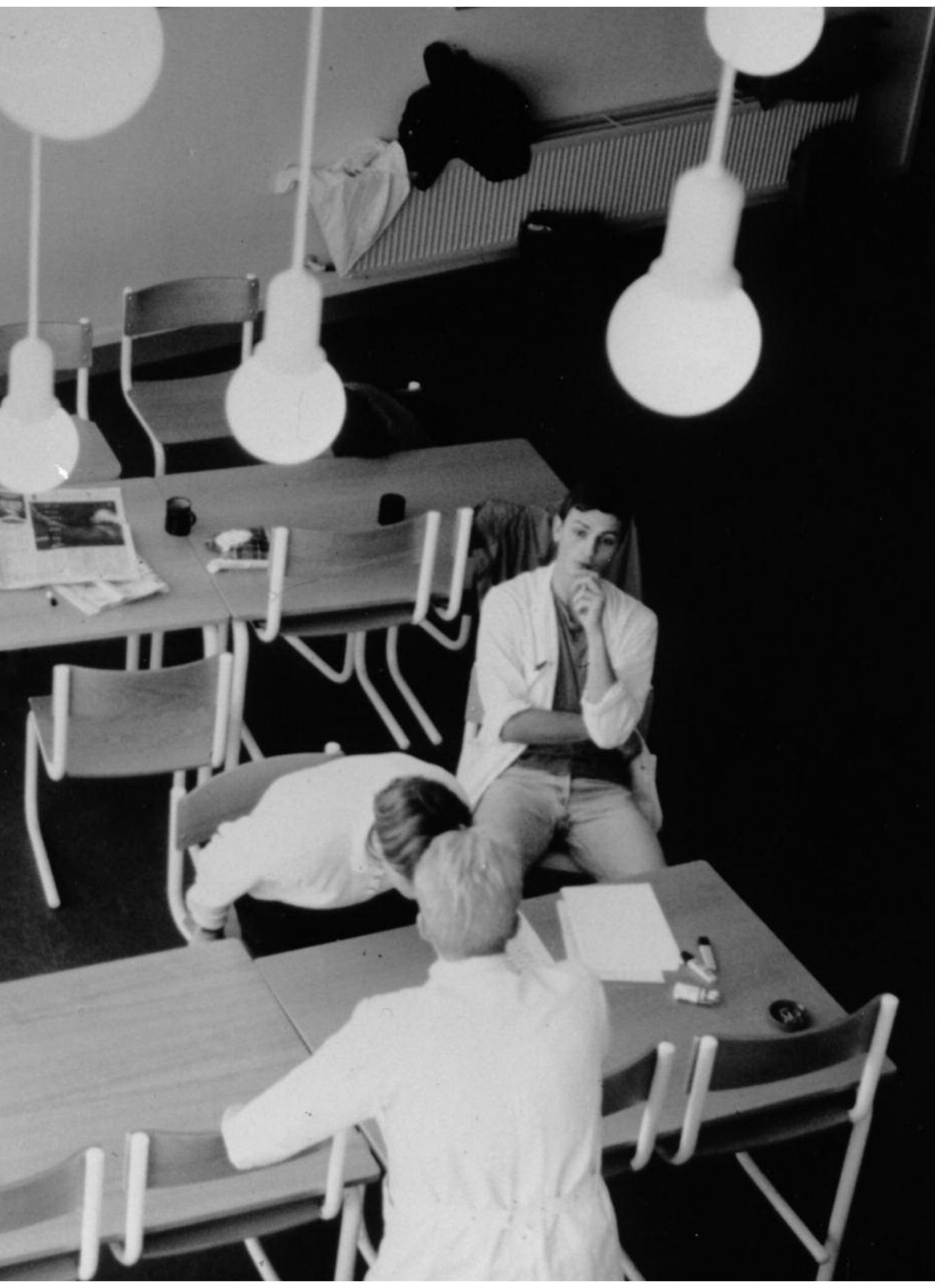


På baggrund af gennemlæsninger af udskrevne interview er udsagnene "kodet" tematisk med angivelse af sammenhængen i interviewet. Gennem bearbejdningen opstår også nye temaer, ligesom bearbejdningen af andre interviewtemaer understøtter eller differentierer de her fremlagte tolkninger af de studerendes udsagn om køn. Vores tolkninger er endvidere inspireret af vores forforståelse, vores teoretiske baggrund og af andre empiriske undersøgelser.

Denne artikel er en sammenfletning af et beskrivelses-lag og et tolknings-lag. Den er bygget op om, hvad der siges om køn i form af citater eller parafraser og nogle steder antydes sammenhængen med stikord.

\section{Problematisering AF KØNSPOLARISERINGER}

Hvad er det så, der siges om køn, og hvordan siges det, med hvilke ord og begreber? Det er som angivet et af de filtre, vi lægger ned over teksterne. Indledningsvis er det imidlertid vigtigt at markere én kontekst, der er fælles for de fleste af de studerendes udtalelser om køn, men mest eksplicit fremhævet af de studerende på nordisk. Når der siges noget om kvindelig og mandlig, kvinder og mænd, indleder de studerende som oftest med at lægge afstand til en dikotomisk og essentialistisk forståelse af køn. De giver med kritisk distance udtryk for, at når de efterfølgende udtaler sig om køn, vil de blive "generaliserende", "deterministisk", "biologistisk" eller "firkantet". De modificerer også deres udtalelser om køn ved at tale hypotetisk om kønsforskelle og ved indskydelse af et "måske".2

\section{HVORDAN TALER DE KVINDELIGE STUDERENDE PÅ NORDISK OM KØN?}

$\mathrm{Vi}$ vil lytte til brudstykker af et interview med tre kvinder i en delvis parafraseret udgave. Helle fortæller om den specialegruppe, som hun har fået dannet, og siger så: "Det hjælper meget, at der er en mand, så er der ikke sådan "hønsesnak", og man arbejder." Den enlige mand, fortæller hun, gider ikke det der hønsesnak.

Senere fortæller Ingelise om sin specialegruppe, som nu mødes sjældnere: "Vi snakker også sammen en gang imellem og mødes lidt, men der går meget social snak i det, synes jeg ... Der går andegård eller hønseri i det. Så har vi sagt: "Vi nyder at være sammen. ... Vi har meget at give hinanden og snakke om også. Så vi har sådan set droppet at snakke speciale sammen ...."

Da Ingelise igen făr ordet, siger hun med reference til et meget omtalt avisinterview med universitetscensor Thorkild Kjærgaard (1998):3 “Der er måske lidt rigtigt i det der med kvinder. Af hensyn til hinanden og nogen gange for at være gode ved hinanden, kommer de til at hæmme hinanden. Så selv om man kan se, at de har det skidt, så bakker man dem lidt op i stedet for at få dem til at tage fat og ændre deres liv ... Altså i god mening, der hæmmer vi måske hinanden lidt, i stedet for måske at sige, at så lad ham overtage ansvaret derhjemme. Du er ingen ravnemor af den grund." Og Ingelise fortæller om sin egen skilsmisse. Helle tager over ved at fortælle lidt af sin historie. Manden er pendler, så hun er alene med børnene i hverdagen. Hun kunne aldrig selv have valgt børnene fra. Det er fordi:

"Jeg føler en større omsorg, end jeg kan mærke min mand gør, selv om han er en fantastisk far. Altså der tror jeg, at det er medfødt hos kvinder ...”

Sara refererer i et individuelt interview også til universitetscensoren. Han har i hvert fald én vigtig pointe, siger Sara, og det er, at kvinder let bliver "nikkedukker" for hinanden. De bliver "rygklappere" i stedet for at manifestere deres uenighed og derigennem udfordre hinanden. Der er meget, der forbliver usagt. Hun fortæller videre om den indbyrdes konkurrence og misundelse, der er mellem hende selv og to andre kvindelige studerende, der har et fagligt samar- 
bejde. Samtidig kan de enormt godt lide hinanden og er til stor hjælp for hinanden. "Men”, siger Sara, "det er for eksempel et fy-ord at sige: Jeg er bedre end dig!" - og hun tilføjer: "Sådan, har jeg det også selv."

Hvad disse studerende kvinder fortæller er:

* at kvinder har svært ved at adskille fagligt og socialt;

* at kvinder støtter hinanden, men også at kvinder hæmmer hinanden;

* at konkurrence og misundelse kan være en skjult dagsorden blandt kvinder;

* at kvinder kan og bør handle anderledes end de handlemåder, der traditionelt tilskrives kvinder.

Kvinderne fortæller gerne med eksempler, de fortæller personligt reflekteret, selvkritisk og kvindekritisk. Disse kvinder siger, at de kan tage ansvar for ændringer i deres eget liv i stedet for at leve med frustrationerne. De siger også, at de kan tage ved lære af mænds måder at praktisere fællesskab på: at opfatte uenighed som et fagligt problem og ikke et personligt problem og at undgå skjulte dagsordener. Når den kønsdikotomiske tænkning tager over, så bliver det mandlige beskrevet som et positivt modbillede til det kvindelige.

\section{HVORDAN TALER DE KVINDELIGE STUDERENDE PÅ KEMI OM KØN?}

I interviewene med de kemistuderende kvinder kommer køn som oftest på tale $\mathrm{i}$ forbindelse med studiet. Merete fortæller for eksempel, at "overvægten af mænd giver lidt mere 'mandehørm'", men hellere "mandehørm" end "hønsegård". Hun siger, at stemningen mellem kvinder præges af sladder og intriger, hvor der skumles $i$ stedet for, at der åbent siges til og fra.

I gruppen med Berit stilles spørgsmålet: "Hvordan har I det med at være på en uddannelse med så få kvinder?" Berit svarer promte: "Det er ikke noget problem. Hu- maniora er frygteligt. Er der for mange kvinder, så bliver de intrigante. De snakker for meget om noget, der er irrelevant. Det gør de, når der er gruppearbejde." Hun siger også, at fyre er anderledes. "Fyre er sådan lidt mere: Lad os lige koncentrere os om det her og gøre det færdigt, så kan vi gå ned i kantinen og spille rollespil bagefter." Mænd kan drille hinanden mere kammeratligt, er hendes slutkommentar.

Lise udtaler, at hun ikke ønsker flere kvinder på studiet, for de vil være tilbøjelige til at danne kliker. Hun siger: "Piger er meget sådan pylrede. Mænd er meget mere rationelle end kvinder er. Det kan jeg godt lide." I stedet for kvinders svævende følelser, så sætter mænd sig ned og analyserer, siger hun.

Rie er sikker på, at flere piger på studiet vil give en helt anden stemning - "fordi piger - måske - er lidt mere snik-snak. Pludder, pludder, pludder". Hun nævner et eksempel, hvor hun selv snakker i stedet for at koncentre sig om undervisningen, og bliver korrekset af sin ven. Og hun konkluderer: "Jeg tror måske, at kvinder er mere glade for at snakke, også når det ikke lige er på sin plads." Piger har også en tendens til at sladre og bagtale. Det gør mænd ikke i så høj grad.

Hvad disse kemistuderende kvinder fortæller er:

* at kvinder danner kliker;

* at kvindefællesskaber er præget af intriger og skjulte dagsordener;

* at kvinder er tilbøjelige til at snakke og pludre;

* at kvinder ikke kan holde den sociale snak ude og koncentrere sig om det faglige.

Kvinderne fortæller med personligt oplevede eksempler og ofte med reference til studiet. De fortæller om, hvad det vil betyde, hvis studiet bliver kvindedomineret, og der fortælles i modsætninger mellem kvindeligt og mandligt. Det positive modbillede til de stærkt kritiserede kvindefællesskaber er 
mandlige studerendes studieadfærd og praksisfællesskaber.

\section{SOCIAL KONTRA FAGLIG}

Fælles for de kvindelige studerendes tale er, at de med forbehold modstiller kvindemand, kvindeligt-mandligt, når de bringer køn på bane. Fælles er også de negativt ladede beskrivelser af relationerne mellem kvinder i praksisfællesskaber. Kvindelige relationer sammenfattes i kulturelt overleverede metaforer som "hønsesnak" og "hønsegård". ${ }^{4}$ Men "hønsesnak" synes brugt i to betydninger. Hønsesnak synes synonymt med samtale om noget uvæsentligt. Det er den snak, som Rie sammenligner med et barns pludren. Ries afvisning betyder ikke nødvendigvis, at "snak" er en overflødig social kommunikationsform. Men i forhold til et studium og til fagligheden, er den både irrelevant og en hindring for en faglig koncentration.

Hønsesnak bliver imidlertid også brugt i en mere omfattende betydning: om socialt samvær mellem kvinder. I omtalen af et sådant samvær indgår imidlertid både positive og negative træk. Det er på den en side rart og givende at være sammen, men på den anden side dannes der kliker, og der skabes intriger. Det er især kvinder på nordisk, der fortæller om de positive sider, og som i næste åndedræt vender vrangen ud, og fortæller om negative træk, såsom at kvinder hæmmer hinanden. Fremstillingerne af samvær skifter mellem, at der fortælles mere personligt om smertelige erfaringer, og at samvær ses "udefra", hvor det er traditionsbundne kvindenedvurderende stereotypier, der dominerer sproget.

Men hvad enten hønsesnak står for en social indholdstom snak eller for et socialt fællesskab med negative og positive sider, så har kvinder yderligere en svaghed: De har en tilbøjelighed til at blande socialt og fagligt. Mandlige studerende er bedre til at være faglige og koncentrere sig og samtidig bevare humoren. De siger ting mere direk- te uden at blive personligt fornærmede. "Social" har således fortrinsvis en negativ betydning, når der henvises til kvinder og kvindeligt, og kvindelig socialitet modstilles både mandlige praksisfællesskaber og faglighed.

Analysen af kvindelige studerendes udsagn om kvinder har sin parallel i Dorte Marie Søndergaards interviewundersøgelse med studerende på universitetet (1996). Søndergaards analyser viser, hvordan social i de studerendes fortællinger forbindes med noget, der er knyttet til blød og kvindelig, og som er modstillet hård og maskulin. Men social forbindes også, ifølge hendes undersøgelse, med noget, de fleste både kvinder og mænd, gerne vil have mellem sig, uden at det i særlig høj grad understreges som noget, der står i modsætning til det faglige (ibid 1996, 334 ff.). Hun skriver, at det besværlige ved at dyrke eller udvise socialitet forstået som blød og kvindelig er, at den ikke værdsættes i den akademiske kultur. Den er koblet med lav prestige, med følelser og subjektivitet, og i den betydning af social udpeges den som farlig og fremmed for akademisk faglighed. Akademisk faglighed kobles med seriøsitet, faglighed, saglighed og stringens.

Den form for socialitet som alle "gerne vil have imellem sig", fremtræder i nogle kvindelige kemistuderendes omtaler af kantinesnak og især af arbejdet i laboratoriet. I min udlægning er det den særlige form for socialitet, som kan udvikles i en gruppe, der har et fagligt fællesskab. Jeg vil derfor tale om en fagligt integreret socialitet og herved forstå uformelle omgangs- og samværsformer, som af de involverede opleves som noget, der fremmer samarbejdet og øger kvaliteten af "fagligheden". Et socialt praksisfællesskab kan rumme en sådan fagligt integreret socialitet, selv om praksisfællesskaber også kan præges af positionskampe. Ifølge kemikvindernes beretninger indgår de først i et sådant fællesskab, når de tilknyttes en afdeling med deres eget laboratorieprojekt. 
Skal den positive side af den socialitet, som tilskrives kvinder, opleves som en resurse $\mathrm{i}$ et studieforløb, så synes det at forudsætte, at der sker en omvurdering, der gør den legitim. Men hvem skal konstruere en sådan forståelse på et universitet, der på VIP-siden er mandligt domineret, og som af de fleste undervisere og studerende opleves som kønsneutralt, og hvor faglighed og en fagligt integreret socialitet er i højeste kurs?

\section{KRITISK SELVREFLEKSION}

Den kritiske selvrefleksion er mest fremtrædende $\mathrm{i}$ interviewene med de kvindelige studerende på nordisk.

Jeg vil her følge brudstykker af Saras biografi, som hun fremstiller den i interviewet. Det er Sara, der sætter ord på det, som hun mener, er det usagte i den kvindegruppe, hun er deltager i på instituttet: den indbyrdes konkurrence og misundelse. Hun kalder dem fy-ord og tilføjer: "Sådan er jeg også selv." Sara fortæller om sit faglige engagement, om sine faglige ambitioner, og om hvordan hun lige nu over for kæresten insisterer på, at specialet har førsteprioritet. Hun fortæller om at være strategisk for at styrke sit specialeområdes udvikling og om bevidst at bruge sin ungdom og sin kvindelighed for at opnå en faglig position i en totalt mandsdomineret faglig sammenhæng uden for instituttet. Gennem interviewforløbet fortæller Sara således flere gange om sig selv som én, der bryder med traditionel kvindelige adfærdsmåder, og samtidig i særlige situationer bevidst bruger sin kvindelighed for at blive fagligt synlig.

Mod slutningen af interviewet udbryder Sara: "Jeg synes lige pludselig, at jeg er kommet til at se så hård ud," og hun fortæller, at hun forud for interviewet havde besluttet sig for at være ærlig, men nu synes hun, at det hun gør i denne periode af sit liv, er mangelfuldt. På den anden side er det vigtigt for hende at skabe sig en karrieremulighed for at klare sig. Men: "Der bli- ver skabt et billede af mig, som om jeg er umenneskelig. Det bryder jeg mig ikke om, men sådan er det jo bare lige nu." $\mathrm{Og}$ da vi er færdige med de sidste temaer og enige om at slutte, siger Sara: "Et eller andet sted var det vigtigt for mig at sige det der med, at jeg er kommet til at se ud som den store stygge ulv, og det vil jeg ikke. Så sidder jeg og tænker bagefter, at det er noget pjat, at det er kvindeligt. Det tror jeg absolut. Det gør mig lidt arrig, at jeg skal sidde og undskylde mig selv."

Saras projekt er, når vi følger hendes egen fremstilling, dels at bryde med sin sociale baggrund, dels at holde fast i og prioritere sit faglige engagement og sin karrieremulighed og dels at overskride nogle traditionelle kvindelighedsnormer ved at italesætte det utilladelige og at udvikle alternative handlemuligheder. Men hun tilkendegiver også usikkerhed $\mathrm{i}$ forhold til sin egen konstruktion, og den selvfremstilling, hun giver $\mathrm{i}$ interviewet. Hun søger at forklare sig, men siger så, at hun kan ikke lide, at hun undskylder sig, og dermed falder tilbage i en kvindelighedsnorm.

Saras beretning forstår jeg som udtryk for, hvor uhyre krævende det kan være for en kvindelig studerende at skabe sig både en køns- og en fagligheds-identitetet i et universitetsmiljø. Jeg finder, at der gennem Saras fortælling, tegnes nogle mulige kønnede barrierer for en forskerkarriere. Nogle vil kalde dem psykiske. Jeg mener, at universitetets kultur er med til at konstruere dem.

Før de mandlige studerende får ordet, vil jeg foreløbig konkludere, at der i de kvindelige studerendes forståelse af kvindelighed indgår, at de med kvindeligheden som bagage ikke kan adskille socialt og fagligt, og at den faglige norm forbindes med "seriøsitet, faglighed, saglighed og stringens”, som anses for mandlig. Kvinder må derfor disciplinere sig selv. Derudover er den mandlige form for fagligt integreret socialitet efterstræbelsesværdig. 
HVORdAN TALER DE MANDLIGE STUDERENDE PÅ NORDISK OM KØN?

Køn dukker sjældnere op som tema i interviewene med de mandlige studerende. I et gruppeinterview fortæller Andreas og Ivar begejstret om en lyrikgruppe, som de dannede tidligt i studiet. Lyrikgruppen eksisterer stadig. I det individuelle interview fortæller Andreas igen om lyrikgruppen. Nu er det mændene, der er tilbage. De mødes jævnligt. Ind imellem går de også i biografen eller på café, og her inviteres kæresterne somme tider med.

Indledningen til Andreas' beretning er ordene: "Der er også et andet mønster." Fortællingen berettes som en alternativ samværsform til det samarbejde, som han har haft med kvinder og mænd i sin studietid. Han siger, at forskellen på mænd og kvinder måske er, at kvinder er mere socialt anlagte fra begyndelsen. I gruppeinterviewet bemærker han, at han trak sig ud af et vejledningsforløb, hvor den kvindelige lærer samlede hele "hønseflokken", så de kunne sidde og snakke om teksten. Det fik han ikke noget ud af.

Andreas lægger vægt på at skelne mellem fagligt og socialt og mellem fagligt og personligt, når han omtaler den ideelle faglighed og den gode underviser. Han siger, at der ligger en maskulin værdi i at fastholde vandtrtte skodder mellem det personlige og faglige.

I Andreas' beretning er socialt-fagligt på spil i forskellige sammenhænge. I lyrikgruppen skelner de mellem sociale sammenkomster og aftener, hvor lyrikken er temaet. "Hønseflokken" sidder og snakker om en tekst, hvilket ikke er tilstrækkeligt fagligt givtigt. Faglighed rummer ikke det personlige.

I en anden gruppe fortæller Asger om et meget intenst samarbejde med en ven i de første studieår. De havde både fælles interesser og supplerede hinanden fagligt. Men "spillet mellem det faglige og det sociale, det er mest kvinder, der kan det," siger han. Og for Asger er der forskel på kønne- ne. "Man skal være stolt af sit eget køn", siger han. "Derfor skal gruppearbejde ikke blive kønsløst." Det sidste er en replik til de to andre i gruppen. Lars har lige udtalt, at køn ikke gør en forskel i et gruppesamarbejde, og Knud har uddybet den opfattelse med at sige, at det ikke er køn, men mennesket og det at man har et åndsfællesskab, der er vigtigt.

I det individuelle interview uddyber Knud sin forståelse af køn. Den bedste forklaringsmodel er, synes han, køn som en kulturel og social konstruktion, selv om den ikke rækker til at forstå hans lille søns "han-adfærd" eller til, at det er hans kone, der er den bedste "opdrager" og omsorgsgiver. Senere overvejer han, hvorfor kvinder er dem, der bedst klarer de rent pragmatiske krav i studiet. De består "flittighedstesten", siger han. Han forestiller sig, at der er tale om et socialiseringsfænomen: Piger er i deres skoletid blevet "honoreret for at sidde stille på deres pind og se flittige og glade ud". Her under specialestudiet, er han af økonomiske grunde selv sporet ind på at være den flittige studerende, fortæller han, og han beklager det.

Hvad de mandlige studerende på nordisk fortæller om køn er:

* at et mandevenskab og en mandegruppe både kan rumme et socialt fæellesskab og et fagligt samarbejde, men hver ting til sin tid; * at faglighed blandt andet består $i$ at holde det personlige ude;

* at kvindelige studerende måske har mindre fagligt engagement og selvstændighed.

Mændene fortæller gerne med eksempler og personligt reflekteret; men kun få udtaler sig med et kritisk blik på mandlighed og egen kønsidentitet. Til forskel fra det positive mandlighedsbillede og kritiske og selvkritiske kvindelighedsbillede, som tegnes af kvindelige studerende på nordisk, tegner der sig et positivt selv- og mandlighedsbillede med enkelte ridser og et negativt ladet billede af kvindelige studerende gennem in- 


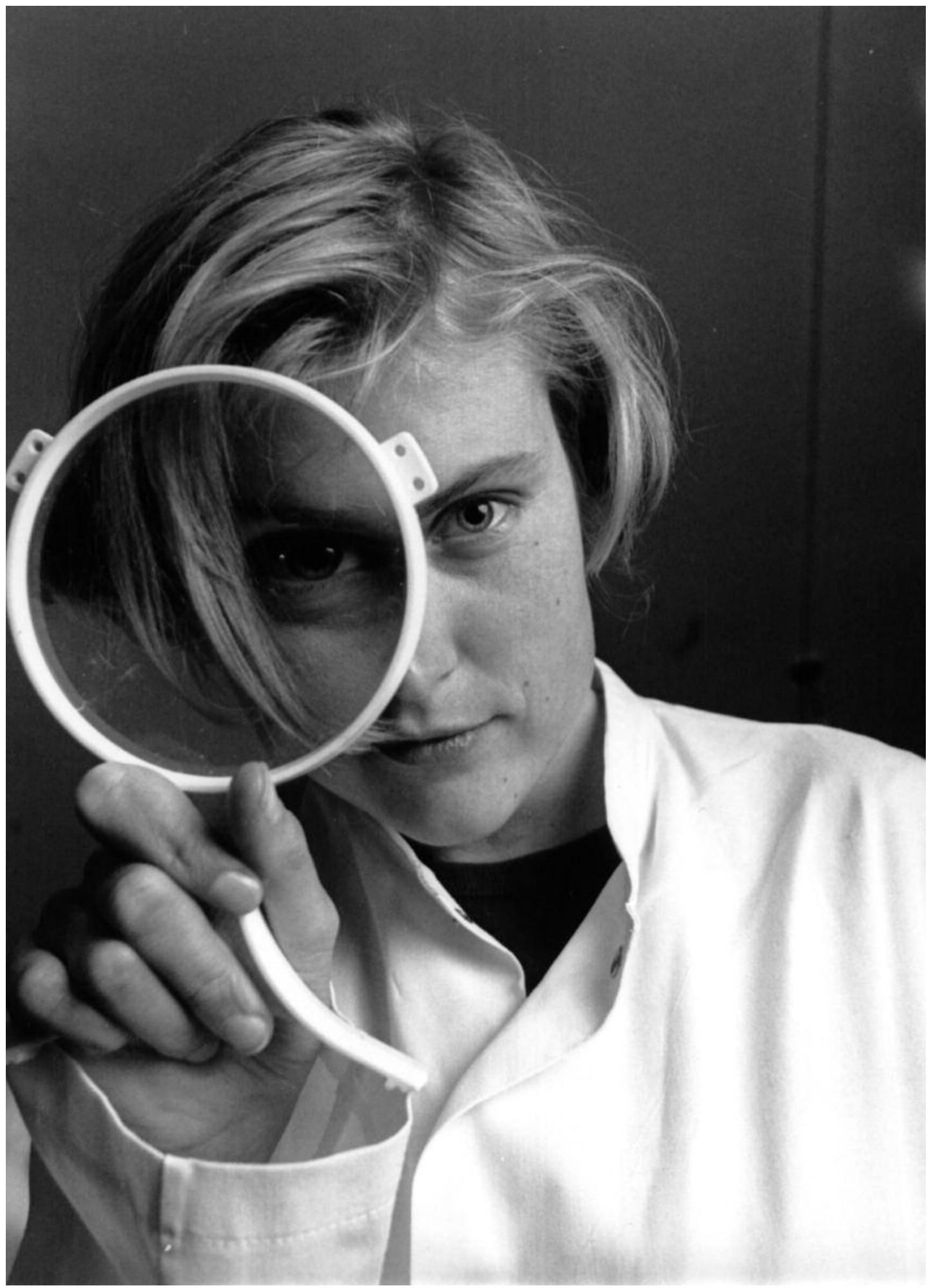


terviewene med de mandlige studerende. Dog giver de mandlige studerende eksempler på positive træk, når de fortæller om konkrete kvinder som konen eller kæresten.

\section{HVORDAN TALER DE MANDLIGE STUDERENDE PÅ KEMI OM KØN?}

De mandlige studerende på kemi fortæller som de kvindelige studerende næsten udelukkende om køn i sammenhæng med kemistudiet. Først og fremmest omtales "nørden": den mandlige kemistuderende, der er fagligt dygtig, men som ikke fungerer socialt. Kvindelige nørder kendes ikke, siges det. Helge leverer en opsummering af, hvad denne type står for, da han siger: "Der er måske en overvægt her af mennesker, der ikke er tjekkede, og som ikke rigtigt fungerer uden om, men der er også mange, der ikke er socialt afmonterede."

I et gruppeinterview diskuteres kvinderne på kemistudiet. De to af de tre mænd udtaler, at kvinderne er kedelige og ikke som piger fra andre studier, der kommer i kantinen: "Man kan tydeligt se, okay, at det er én, der ikke kommer fra kemi - på påklædningen, for de gør mere ud af påklædningen." Ingen piger er imidlertid nørder, det ligger ikke til piger. Det, mændene forhandler om i gruppeinterviewet, er, hvorvidt piger på kemi er mere eller mindre kedelige end andre kvindelige studerende, og hvorvidt de overhovedet bliver gift. Den ene har en kæreste blandt de studerende, så der er måske også lidt drilleri med i spillet.

Helge er den eneste, der ræsonnerer over forskelle mellem sig selv som mandlig studerende og sine kvindelige medstuderende. Han beskriver sig selv som meget rationel og logisk tænkende og siger, at han er meget lidt åben, hvis han vurderer, at hans mening eller opfattelse er den rigtige. Han fortæller, at han altid har været ivrig efter at løse problemer både af ren og skær interesse, men også ud fra en udpræget sportslig konkurrence-ånd. Han mener, at man er nødt til at være præcis, når man taler kemi.
Det betyder, at man i diskussioner kører meget hårdt mod hinanden. "Det ved jeg ikke, om der er nogen piger, der ikke synes, at det er rart, men det er oftest drengene der deltager i diskussionerne. Det er faktisk flest drenge, tror jeg." Det er heller ikke pigerne, der råber op og virkelig ønsker en diskussion. "Jeg tror også, at der er et vist element der, at drengene buser meget mere frem end pigerne."

Han siger, at et af problemerne for piger måske er, at de ikke er så gode til at sælge sig selv og oftere er grundigere i opgavesammenhæng end drengene. Han har tænkt meget over det der med drenge og piger og diskuteret det med sin kvindelige studiekammerat. Han fornemmer, at "piger bruger en masse tid på opgaver, at de sidder og fitter med dem i stedet for at forstå, hvad det egentlig handler om, hvad løsningen siger os, eller hvorfor der er større sammenhæng i problemerne. Sådan var det også i gymnasiet: Pigerne sad og fedtede med tingene og skrev, skrev, skrev. Det er jo også både godt og skidt."

Helge fortæller således, at der efter hans opfattelse måske er forskel på kvinders og mænds studieadfærd. Han udtaler sig kritisk om nogle træk, som han mener måske karakteriserer kvindelige studerende, og som ikke passer ind i den faglighed, som han tillægger kemi, og han vurderer, at deres manglende diskussionslyst giver dem problemer $i$ forhold til deres selvtillid. Imidlertid fremhæver han også den betydning, som samarbejdet med en dygtig kvindelig studerende har for deres fælles udbytte, fordi de komplementerer hinandens synsvinkler.

I en eftersnak siger den ene af deltagerne $i$ et gruppeinterview, at han synes, at det vil være herligt med flere kvinder på studiet. Det vil da give et bedre studiemiljø. På et kollegium er "munkegange" i hvert fald ikke rare, selv om "pigegange" er værre, for der bliver det til "sladder og intriger", men er det udelukkende mænd, så bliver det til “æde- og drikkegilder". 
Hvad de mandlige studerende på kemi fortæller og forhandler om er, hvorvidt kvinder på kemi er mindre kvindelige og kedeligere at se på end andre kvindelige studerende. Der fortælles om nørden og om "pigegange" med sladder og intriger og "munkegange", hvor det sociale består i at æxe og drikke. Men én studerende giver også udtryk for, at flere kvinder måske kan bidrage til et bedre socialt miljø. Og så er der Helge, som fortæller om faglighed og om kvindelige studerende, der ikke har forstået fagligheden. Samtidig er han den eneste mandlige studerende, der henviser til et samarbejde med en af det andet køn.

Der udtales således af nogle kritik af kvindelige studerende og kvindeligt samværsfællesskab. Der er imidlertid to kritiske begreber, der knyttes til mand henholdsvis mandligt samvær. Der er nørden, som ensidigt dyrker fagligheden. Afvisningen af nørden kan tolkes som en indirekte kommentar til forestillinger om den ideelle kemistuderende. Han skal nok være faglig, men han skal også kunne indgå i et socialt fællesskab.

Det sociale fællesskab mellem mænd benævnes af nogle kvindelige studerende som "mandehørm", og to mandlige studerende taler om "munkegang". Det er sproglige begreber, der tilsyneladende modsvarer "hønsesnak" og "pigegang". Men mandehørm og hønsesnak har ikke et identisk indhold. Mandehørm betegner et mandligt samvær, hvor mandighed bekræftes gennem udvekslinger af erotiske og seksuelle fantasier og erfaringer. Her fokuseres der ofte sexistisk på forholdet til kvinder og på kvindekroppe. Hønsesnak er som skrevet et begreb, der både dækker "small talk" og et socialt fællesskab, der kan yde medlemmerne gensidig støtte, men de gensidige relationer mellem kvinder omtales mest negativt, som en skjult kamp om hvem der er inde, og hvem der er ude. Hvor mandehørm som stereotypi omhandler mænd i særlige situationer og deres omtaler af deres seksuelle forhold til og forestillinger om kvinder, så omhandler hønse- snak som stereotypi generelle træk ved kvinder og deres indbyrdes forhold. På "munkegangen" udfolder samværet sig omkring mad og drikke. På "pigegangen" udfoldes de negative sider ved kvindelig socialitet, siges det af mandlige studerende. Igen synes kritikken at gælde mandligt socialt fællesskab i særlige situationer og kvindeligt socialt fælleskab generaliseret.

\section{REFLEKSIONER OVER KRITIK OG SELVREFLEKSION, SOM FORTALT I INTERVIEWENE}

Hvordan kan den kønsforskel, der fremstår i omtalen af eget og det andet køn forstås?

Dorte Marie Søndergaard skriver, at der til kvinder i universitetskulturen er forventninger om et højt niveau for selvrefleksion og refleksion over menneskelige kollektiver, og at disse forventninger spiller sammen med en kvindelighedskonstitution (Søndergaard 1996, 316). Men denne tendens til at medreflektere både de andre og sig selv kan samtidig gøre det vanskeligere at indtage en dominerende position og markere sig i det hierarki og den konkurrence, som er spillereglerne i universitsmiljøet, også ifølge de studerendes udsagn på nordisk og kemi.

Sara fortæller eksempelvis om at prøve at fremstille sig selv som en person, der har besluttet sig for at overtage de mandligt konnoterede spilleregler, som hun opfatter hører til på universitetet. Men hun kan ikke $\mathrm{i}$ interviewsituationen klare denne selvfremstilling. Hvad hun siger er: Jeg vil ikke se ud som en stor styg ulv. Hun siger vel hermed, at hun opfatter sig selv som én, der plejer at handle socialt ud fra en kvindelighedsnorm, hvor hun ikke kun reflekterer over de andre, men også medreflekterer dem i sine handlinger? Man kan forestille sig, at hun ikke længere følelsesmæssigt kan bære ubalancen i det billede, som hun giver af sig selv. Hun afbryder da sin fremstilling for $\mathrm{i}$ stedet at reflektere over det billede, som hun er på vej til bygge op. Om ubalancen bliver mere ubærlig, fordi samtalepart- 
nerne $\mathrm{i}$ interviewet er kvinder, kan der kun gisnes om. Gør forskersubjekterne det sværere for hende at skabe et billede af sig selv som konkurrenceorienteret og strategisk tænkende? Forskersubjekterne, der interviewer, er midaldrende kvinder, der kan forventes både selv at være bærere af og repræsentere de kulturelle forventninger til kvinder om kollektiv omsorg, medrefleksion af de andre og ikke-dominant tænkning. Eller kan det tænkes, at der i løbet af interviewet bliver fremprovokeret en stærkere markering af en kvindelighedskritik, fordi interviewerne er kvinder, der er i den forskerposition, som Sara stræber efter?

Interviewene med de mandlige studerende rummer færre kritiske og selvkritiske udsagn. Det kan hænge sammen med en mandlig fællesskabsform. Det kan skyldes, at det ikke hører med til de kulturelle forventninger om mandlighed at tale om sig selv og om følelser i et offentligt rum. Dorte Marie Søndergaard skriver således, at følelser og relationer kun tematiseres i situationer, hvor de tilstedeværende mænd har indgået en kontrakt, dvs. har tilkendegivet overfor hinanden, at der er skabt et fortrolighedsrum. Et sådant fortrolighedsrum benævner hun et "undtagelsens rum" (Søndergaard 1996, 289). Uden for sådanne forhandlede fortrolighedsrum, hvor kun mænd er til stede, er det kun i samvær med en kvinde, at følelser kan italesættes. Interviewene med en mandegruppe, men med to kvindelige interviewere opfylder ikke betingelserne for at skabe et fortrolighedsrum. Det kan være baggrunden for fraværet af kritiske refleksioner omkring mandlighed på nordisk og kemi.

I det individuelle interview fortælles der personligt reflekteret af flere mandlige studerende om deres forhold til fagligheden og til studiets krav. ${ }^{5}$ Mandligt praksisfællesskab, mandlighedstræk eller mandlige værdier problematiseres ikke. Måske har Søndergaard (ibid, 325-326) ret, når hun skriver: "Når drenge taler sammen om det, drenge har sammen, så kommer der oplev- elser af varme og solidaritet ind i fortællingen om flokken, konkurrencen og de højtråbende og selvmarkerende samtaler"?

Derimod udtaler kvinderne i interviewene på nordisk og kemi sig anderledes end kvinderne i Søndergaards undersøgelse, hvor mange giver udtryk for, at det mænd har sammen, ser de "som noget underligt overfladisk formålsløst noget, som mere destruktivt end konstruktivt." De kvindelige studerende på nordisk og kemi giver tværtimod positive beskrivelser af det, som mænd har sammen. Søndergaards beskrivelse af, hvad mænd siger om det, som kvinder har sammen, dækker til gengæld også det lidt, der siges i interwiewene med de studerende på nordisk og kemi, nemlig at det “omtales som uvedkommende, som pigesnak og intrigemageri." Når kvinder fortæller om det, som kvinder har sammen, "så kommer varmen og solidariteten ind i fortællingen om at kommunikere med nogen, de bruger samme kommunikationsform som én selv og som er optaget af samme type refelksioner ..." skriver Søndergaard (ibid, 325326). Det sker også, når studerende på nordisk og kemi fortæller; men i deres fortællinger om kvindeligt praksisfællesskab er det dominerende de negative billeder. Endelig udtaler de kvindelige studerende på nordisk og kemi sig ambivalent om det, som kvinder har sammen.

Når jeg har vendt og drejet spørgsmålet om at tale kritisk selvrefleksivt om eget køn, så er det under den synsvinkel, at optagetheden af den kritiske refleksion, som den fremstilles af de kvindelige studerende på nordisk og afvisningen af kvindelige praksisfællesskaber, som den fremtræder i interviewene med kvindelige studerende på kemi, må antages at være en barriere i forhold til en universitetskarriere. Som vist af Susanne V. Knudsen er de studerende på nordisk indforståede med legitimiteten af den akademiske socialisering og de akademiske krav, selv om der er enkelte, som taler om, at der i tillæg kunne være en større praksisorientering (Knudsen 1999). 
De kemistuderende taler med respekt om studiets faglige kvalitet. Men at mestre fagligheden betyder i kvindernes fortællinger at mestre mandlighedstræk, som både angår det at forholde sig rationelt, logisk, analyserende og at vise sine kompetencer $\mathrm{i}$ konkurrence med andre studerende og undervisere ved eksempelvis at stille kritiske eller korrigerende spørgsmål.

Denne mestring betyder også, at de kvindelige studerende lægger afstand til eller holder fagligheden adskilt fra den form for socialitet, som knyttes sammen med kvindelighed. På kemi fortælles der om en anden form for socialitet, nemlig den der er forbundet med fagligheden: den fagligt integrerede socialitet. Den berettes der især om af de kvindelige studerende, der gennem speciale/forskningsprojekt knyttes til en afdeling og derigennem bliver legitime, men mere eller mindre fuldgyldige deltagere $\mathrm{i}$ et praksisfællesskab.

\section{AFsLUTNING}

Gør køn så en forskel? På baggrund af analyser af, hvad der siges om køn, vil jeg konkludere, at køn gør en forskel, i og med at faglighed knyttes til en mandlighedsnorm, og $\mathrm{i}$ og med at denne norm ekskluderer den socialitet, der forbindes med kvindelighed. Denne forskelssætten har som konsekvens, at kvindelige studerende må afskrive den socialitet, som de kulturelt set forventes at varetage. Samtidig må de synliggøre sig gennem konkurrence og finde vej i hierarkiske strukturer. Det "identitetsarbejde" synes de at tage på sig, når de taler om at være studerende og om at gøre køn anderledes. De vil have fagligheden, og kun få ønsker den ændret. Forskerrekrutteringsundersøgelsen peger imidlertid på, at ændringer i feedback-processer og flere undervisningstilbud, der indbyder de studerende til at deltage i faglige fællesskaber, kunne befordre alle studerendes - men især kvindelige studerendes - udvikling af faglig identitet.

\section{Noter}

1. En mere omfattende udredning af "Gør køn en forskel?” findes i Reisby (1999), kapitel 5, 61-85.

2 . I en spørgeskemaundersøgelse af ingeniørstuderende problematiserer informanterne dikotomiske udsagn i deres kommentarer til spørgsmålene (Kolmos 1991).

3. Kjærgaard (1998) fremsætter en række kritiske kommentarer til, hvad der sker, hvis kvinder kommer til at dominere et fag. Det medfører "en forringelse af fagenes status". Der sker tillige det, at "de fastsætter deres egne spilleregler. Kvinder trækker hinanden ned og gør det nemt for hinanden." "Deres sociale indfølingsevne får dem til at synes, at alle skal være med, at ingen skal udst $\varnothing$ des." "Kvinder er tilbøjelige til at helgardere sig" og "grave sig ned i perifere problemstillinger", men den ypperste prestation skabes i hård konkurrence.

4. I 1970'erne dannedes forlaget Hønsetryk, der blandt andet udgav bogen Hønsestrik. Drude Dahlerup skriver: “Navnet 'hønsestrik' er igen et eksempel på rødstrømpernes metode med at tage fat i det kvindeundertrykkende - kvinder kagler jo som høns - og vende det om og give det et feministisk indhold (Dahlerup 1998, Bind 1, 579, note $62)$.

5. Se Susanne V. Knudsen (1999) for en uddybning af køn og faglighed på nordisk.

\section{LITTERATURLISTE}

- Dahlerup, Drude (1998): Rødstrømperne. Den danske Rødstrømpebevagelses udvikling, nytenkning og gennemslag 1970-85. Bind 1 og 2. Gyldendal, Danmark.

- Det Kongelige Videnskabernes Selskab (1992 og 1993): Forskerrekruttering I og II.

- Hansen, Kirsten Grønbæk (1991): Kvindelige forskere i samfundsvidenskaberne og humaniora. Hvorfor bliver de usynlige, og hvorfor lægger ingen mærke til dem?, in K. Grønbæk Hansen et alia (red.) Myter, strukturer og selvforståelser - undersogelser af konnets betydning $i$ uddannelse og arbejde. Serie om fremtidsforskning no. 29, Ålborg Universitetsforlag, Aalborg.

- Jensen, Hanne Nexø (1997): Det forskningspolitiske system. En kønsprofilerende beskrivelse af organisering, regler, okonomi og personale inden for forskning og uddannelse. Kon $i$ den akademiske organisation. Arbejdspapir nr. 1. Københavns Universitet, Institut for Statskundskab. 
- Kjærgaard, Thorkild (1998) i interview med Anna Libak. Weekend Avisen 23.-29. januar.

- Knudsen, Susanne V. (1999): Fag og faglighed til fortolkning, in Kirsten Reisby (red.) Kønsblik - på forskerrekruttering $i$ universitetsuddannelser. Danmarks Lærerhøjskole, København.

- Kolmos, Anette (1991): Undersøgelser af køn og holdninger - reflektioner over en forskningsproces, in Myter, strukturer og selvforståelser. Undersogelser af kønnets betydning $i$ uddannelse og arbejde. Red. af Kirsten Grønbech Hansen et al. Aalborg Universitetsforlag, Aalborg.

- Kvale, Steinar (1996): Interview. En introduktion til det kvalitative forskningsinterview. Hans Reitzels Forlag, København.

- Lave, Jean (1999): Læring, mesterlære, social praksis, in Klaus Nielsen og Steinar Kvale (red.) Mesterlare. Laring som social praksis. Hans Reitzels Forlag, København.

- Lave, Jean and Etienne Wenger (1991): Situated learning. Legitimate peripheral participation.

Cambridge University Press, Cambridge.

- Morgan, D.L. (1988): Focus on Groups as qualitative research. SAGE, Newbury Park CA.

- Reisby, Kirsten (1999): Gør køn en forskel?, in Kirsten Reisby (red.) Kønsblik - på forskerrekruttering $i$ universitetsuddannelser. Danmarks Lærerhøjskole, København.

- Simonsen, Dorthe Gert (1996): Kønnets granser. Varia nr. 1, Københavns Universitet, Center for Kvinde- og Kønsforskning.

- Søndergaard, Dorte Marie (1996): Tegnet på kroppen. Køn: Koder og konstruktioner blandt unge voksne i Akademia. Museum Tusculanums forlag, København.
- Widerberg, Karin (1992): Teoretisk verktøyskasse, in Arnhild Taksdal og Karin Widerberg (red.) Forståelser afkjøn. Ad Notam Gyldendal A/S, Oslo.

\section{SUMMARY}

The article deals with what female and male students at two different university studies explicitly say about gender differences in qualitative group and individual interviews. The female students are very critical and sometimes selfcritical of the social intercourse of women and of female social communities of practice, and describe male students' ways of interacting and masculine values as a counterpart. The interviews with male students contain less critical statements on their own social and professional attitudes and ways of interacting, but some negative statements on female social communities and female students' ways of studying. The article discusses how these differences can be understood and in what way they might be a barrier for female students' development of an academic professionalism.

Kirsten Reisby, cand.pæd, lektor, Danmarks Lærerhøjskole, Århus 